\title{
PEDOGENESIS AND SOIL CLASSIFICATION OF AN EXPERIMENTAL FARM IN MOSSORÓ, STATE OF RIO GRANDE DO NORTE, BRAZIL ${ }^{1}$
}

\author{
LUNARA GLEIKA DA SILVA RÊGO ${ }^{2 *}$, CAROLINA MALALA MARTINS ${ }^{2}$, EULENE FRANCISCO DA SILVA², \\ JÉSSIA JULIANA ALVES DA SILVA², REBECA NAIRONY DA SILVA LIMA ${ }^{2}$
}

\begin{abstract}
The Rafael Fernandes experimental farm is located in the Alagoinha district, northwest of Mossoró, State of Rio Grande do Norte, Brazil, over two pedogenic formations of different edaphic characteristics, thus needing a more detailed description of its soil types, since this area hosts several experimental fields for researches on agriculture. The objective of this work was to characterize the morphological, physical, chemical and mineralogical features of the most representative soils of this farm, in order to understand its pedogenesis and define its classifications. The whole area was surveyed in order to assess its more representative pedogenic formations. Three soil profiles were classified and described, from which samples were collected in all horizons for physical, chemical and mineralogical analysis. The parent materials and the relief were the determining factors for pedogenic processes of desilication, podzolization and laterization, generating the three main soil types of the area, which were classified up to the $4^{\text {th }}$ categorical level and described as: Typic Rhodustults (P1), Rhodic Haplustox (P2) and Typic Plinthustalfs (P3).
\end{abstract}

Keywords: Semiarid region. Weathering. Pedogenic processes. Barreiras Group.

\section{PEDOGÊNESE E CLASSIFICAÇÃO DE SOLOS DA FAZENDA EXPERIMENTAL "RAFAEL FERNANDES" NO MUNICÍPIO DE MOSSORÓ, RN}

RESUMO - A fazenda experimental Rafael Fernandes está localizada no distrito de Alagoinha e inserida entre duas pedoformas da região noroeste do município de Mossoró-RN, apresentando características edáficas distintas, o que gera a necessidade de descrições mais detalhadas acerca das classes de solos existentes na área, uma vez que a mesma dispõe de diversos campos experimentais com pesquisas na área de ciências agrárias. Assim, a realização do presente trabalho teve como objetivo a caracterização morfológica, física, química e mineralógica dos solos mais representativos da fazenda a fim de compreender a pedogênese e definir sua classificação. Foram realizadas viagens de reconhecimento de toda a área para a decisão das pedoformas mais representativas e assim definidos três perfis de solo, os quais foram descritos e coletadas as amostras em todos os horizontes para a realização das análises físicas, químicas e mineralógicas. Os resultados permitiram concluir que o material de origem e o relevo foram os fatores determinantes para a ocorrência dos processos pedogenéticos de latolização, podzolização e plintitização, gerando a identificação de três classes de solo principais na Fazenda Experimental que, classificados em $4^{\circ}$ nível categórico, definiram-se como: Argissolo Vermelho Distrófico Típico (P1), Latossolo Vermelho Distrófico Argissólico (P2) e Plintossolo Argiluvico Eutrófico Típico (P3).

Palavra chaves: Semiárido. Intemperismo. Processos Pedogenéticos. Grupo Barreiras.

\footnotetext{
*Corresponding author

${ }^{1}$ Received for publication in $05 / 03 / 2016$; accepted in 07/01/2016

Paper extracted from the completion of course work First author's undergraduate.

${ }^{2}$ Department of Environmental Sciences and Technology, Universidade Federal Rural do Semi-Árido, Mossoró, RN, Brazil;

lunaragleika@hotmail.com, carolmalala@ufersa.edu.br, eulenesilva@ufersa.edu.br, jessia_juliana@hotmail.com, rebecalima@gmail.com.
} 


\section{INTRODUCTION}

The soil is part of the landscape and its distribution is subject to topographical and lithological variations. Different soil types in different reliefs can be related by analyzing the landscape. The soil distribution in a landscape is dependent, in part, by the rocks, climatic conditions and relief, which define the main soil characteristics and morphological properties.

The natural variability of soil types in a landscape is the result of complex interactions between various formation factors: parent material, relief, climate, organisms and time (RESENDE et al., 2014). Soil formation factors and processes define their physical, chemical and mineralogical properties, as well as the agricultural potential of each soil type. Thus, studies involving soil characterization are fundamental for solving problems related to its physical, chemical and morphological processes.

Most of the soils of Mossoró, State of Rio Grande do Norte, Brazil, were formed by associations between the Plio-pleistocene (Barreiras Formation) and Cretaceous (Jandaira Formation) reliefs, with geological composition consisting mainly of limestone of the Jandaira Formation, which forms part the Mesozoic deposits in the Cretaceous period, associated with sedimentary sandstone rocks of the Barreiras Group (CPRM, 2010). The main soil types found in Mossoro are: Ultisols, Aridisols, Alfisols, Vertisols, Molisols, Inceptisols and Oxisols.

The Mossoro northwest region has two distinct pedogenic formations: a large area with Oxisols of medium texture and plain relief in the coast area, and a small area with Ultisols of clayey texture and plain relief in the Chapada do Apodi (SNCLS, 1971). The Rafael Fernandes experimental farm is located between these two pedogenic formations of different edaphic characteristics, thus needing a more detailed description of its soil types. This description is very important for future researches in this area, which hosts several experimental fields for researches on agriculture.

Thus, the objective of this work was to characterize the morphological, physical, chemical and mineralogical features of the most representative soils of this farm, in order to understand its pedogenesis and define their classification. The whole area was surveyed in order to assess its more representative pedogenic formations.

\section{MATERIAL AND METHODS}

The study area was located at the Rafael Fernandes experimental farm, in the district of Alagoinha $\left(5^{\circ} 03^{\prime} 37^{\prime \prime} \mathrm{S}, 37^{\circ} 23^{\prime} 50^{\prime \prime} \mathrm{W}\right)$, northwest of Mossoró, State of Rio Grande do Norte, Brazil, which has approximately 400 hectares. According to Carmo Filho and Oliveira (1995) and the classification of Köppen, the local climate is BSwh', dry and very hot, with a dry season, often from June to January, and a wet season from February to May, annual average precipitation of $673.9 \mathrm{~mm}$ and average relative humidity of $68.9 \%$. The region vegetation type is (Eas) open arborous Caatinga (RADAMBRASIL, 1979).

The whole area of the experimental farm was surveyed in order to assess the more representative pedogenic formations. Three locations were selected and trenches were opened to define their soil profiles. The soils, which were under native vegetation in good preservation conditions, were described and disturbed samples were collected in all horizons according to Santos et al. (2013a), and classified up to the $4^{\text {th }}$ categorical level, according to the Brazilian System of Soil Classification (SANTOS et al., 2013b). The main morphological evaluations considered the horizons height and transition, color, structure, consistency through the profiles, lithology, climate, vegetation, relief and altitude, as described by Santos et al. (2013a). The samples were air dried, ground and sieved in a $2-\mathrm{mm}$ mesh sieve, in order to obtain the air-dried ground soil (ADGS).

Table 1. Location of the described soil profiles

\begin{tabular}{|c|c|c|}
\hline Profiles & Coordinates & Altitude \\
\hline Profile $1(\mathrm{P} 1)$ & $5^{\circ} 3^{\prime} 39,8^{\prime \prime} \mathrm{S}$ e $37^{\circ} 23^{\prime} 44,6^{\prime \prime} \mathrm{O}$ & $78 \mathrm{~m}$ \\
\hline Profile $2(\mathrm{P} 2)$ & $5^{\circ} 3^{\prime} 37,7^{\prime \prime} \mathrm{S}$ e $37^{\circ} 24^{\prime} 15,4^{\prime \prime} \mathrm{O}$ & $90 \mathrm{~m}$ \\
\hline Profile 3 (P3) & $5^{\circ} 3^{\prime} 58,5^{\prime \prime} \mathrm{O}$ e $37^{\circ} 24^{\prime} 3,2^{\prime \prime} \mathrm{S}$ & $76 \mathrm{~m}$ \\
\hline
\end{tabular}




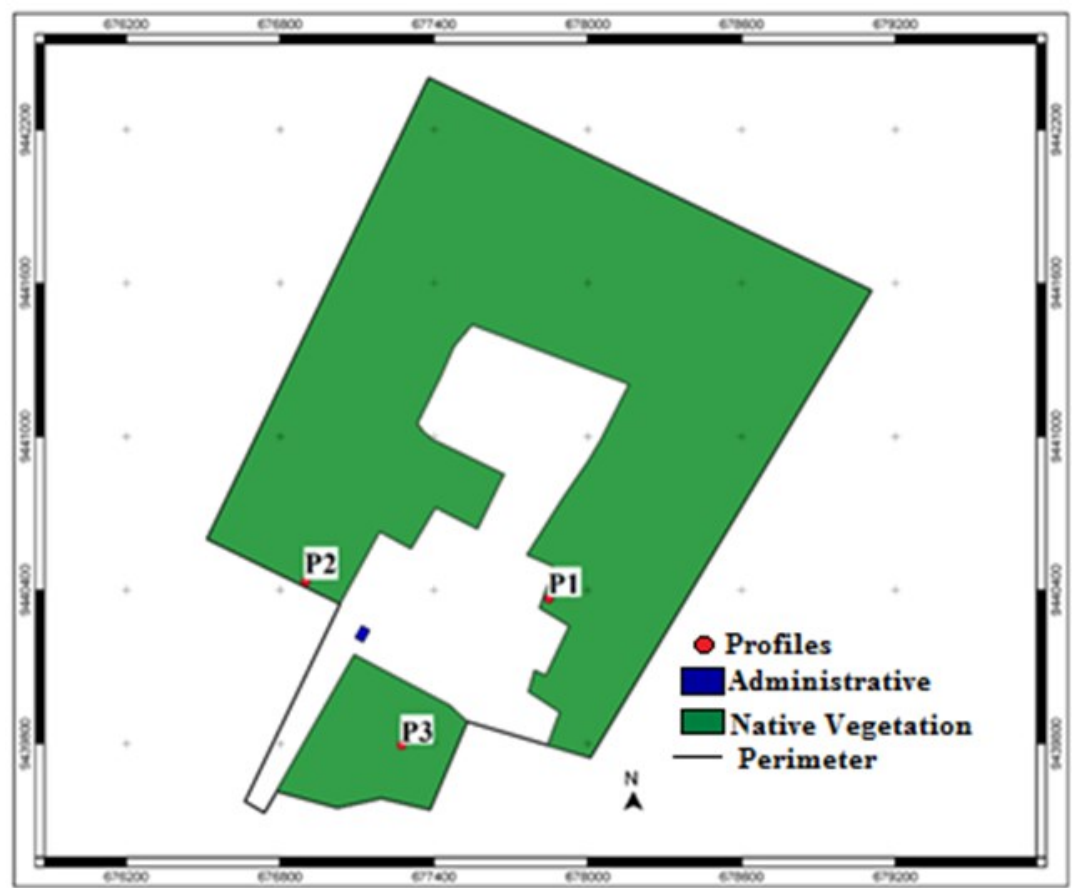

Figure 1. Map of location of soil profiles of experimental farm "Rafael fernandes".

Physical analyzes of the ADGS were performed with three replications. The granulometry was evaluated by the pipette method, according to Donagema et al. (2011).

Chemical analyzes of the ADGS were carried out with three replications, evaluating the $\mathrm{pH}$ in water and $\mathrm{KCl}(1: 2.5)$, P-available extracted with Mehlich-1 and determined by colorimetry, $\mathrm{Ca}^{2+}$ and $\mathrm{Mg}^{2+}$ extracted with $\mathrm{KCl} 1 \mathrm{~mol} \mathrm{~L}^{-1}$ and determined by atomic absorption spectrophotometry, $\mathrm{K}^{+}$ extracted with Mehlich-1 and determined by flame spectrophotometry, exchangeable $\mathrm{Al}^{3+}$ extracted with $\mathrm{KCl} 1 \mathrm{~mol} \mathrm{~L}^{-1}$ and determined by titration, and $\mathrm{H}+$ Al extracted with calcium acetate $1 \mathrm{~mol} \mathrm{~L}^{-1}$ and determined by titration with $\mathrm{NaOH} 0.025 \mathrm{~mol} \mathrm{~L}^{-1}$. The total organic carbon (TOC) was determined by the method proposed by Yeomans and Bremner (1988). These analyzes provided the indices of cation exchange capacity at $\mathrm{pH} 7.0(\mathrm{~T})$, base saturation $(\mathrm{V} \%)$ and exchangeable aluminum saturation $(\mathrm{m} \%)$ (DONAGEMA et al., 2011). Fe was extracted by sulfuric digestion according to the methodology proposed by Vettori (1969), and determined by atomic absorption spectrophotometry.

The mineralogical characterization was carried out by separating the granulometric fractions (Donagema et al., 2011), using only the clay fraction. The identification of the minerals in this granulometric fraction was carried out by X-ray diffractometry (XRD) using a diffractometer (SHIMADZU XRD-6100) and applying the k $\alpha 1$ emission of cooper. The source potential used was $40 \mathrm{kV}$ and the electric current was $30 \mathrm{~mA}$. The scan rate applied was $0.02^{\circ}$ per second. Scanning range

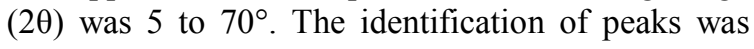

performed with the software X-ray 1.0.0.37 and the minerals were identified according to Chen (1977).

\section{RESULTS AND DISCUSSION}

The morphological, physical, chemical and mineralogical characteristics of the soil profiles evaluated showed the influence of the formation factors parent material and relief in the pedogenic processes, which generated more developed soils, even under their semiarid climatic conditions; expressed by chemical weathering processes, consequently forming more resistant clay minerals. Three main soil types were found in the experimental farm, which were classified up to the $4^{\text {th }}$ categorical level: Typic Rhodustults (P1), Rhodic Haplustox (P2) and Typic Plinthustalfs (P3), which are formations from the pedogenic processes of podzolization, desilication and laterization, respectively.

The morphological attributes had distinct pedogenic characteristics in the studied profiles. P1 showed structures that remains granular in the surface horizons, and changes to subangular blocks in its subsurface horizons due to clay translocation, which changes its structure type (Table 2). The main pedogenic process of the P2 and P3 was not podzolization, however, they also had an increased clay in the subsurface, which classified the P2 in the argisolic sub-group ( $4^{\text {th }}$ categorical level), and the P3 in the Argiluvic sub-order ( $2^{\text {nd }}$ categorical level).

The dry and wet soil consistency was soft and friable, unchanged by the clay concentration in the subsurface in P1, however, due to the clay 
accumulation, its plasticity and stickiness were changed, especially in the subsurface horizons. The wet consistency in P2 indicated plasticity and tackiness from the surface to the deepest horizons, showing that the desilication significantly alters inorganic compounds, forming more stable clay mineral (clay 1:1 and $\mathrm{Fe}$ oxides and $\mathrm{Al}$ oxides) from the first centimeters of the soil, making the Oxisol characterized by a homogeneity of horizons.

A marked change in consistency was found in the P3, especially in the plinthic horizon, with hard, very hard and extremely hard consistencies, both in dry and wet soils, due to the presence of plinthite, which are formed from the weathering of rocks rich in Fe. The accumulation of $\mathrm{Fe}$ oxides, which forms the plinthite, can be identified by a red, yellow-red or dark red mottled material, (SANTOS et al., 2013 b). These mottled material indicate the occurrence of alternating cycles of wetting and drying, that significantly express the geochemical conditions to which the P3 profile is subjected, which is also confirmed by the clear transition between the BA and the Btf horizon. This profile was the only one that had no diffuse transition.

Regarding the parent material, the experimental farm is located over sandstones of the Cenozoic age, known as sediments of the Barreiras Group. The reddish color of the studied soils, with hue of 2.5 YR in most horizons of the P1 and P2 profiles (Table 2) can be explained by the presence of Fe oxides. The color of the P3 differed from the other profiles, with yellowish color mottled material in the surface and intense reddish in the Btf horizon, probably due to the influence of the slightly relief difference of this area, whose altitude is lower compared to the other profiles (Table 2). This lower area may have cyclically accumulated more water, making the environment periodically hydromorphic, segregating the $\mathrm{Fe}$ in the subsurface, which is confirmed by the intense presence of plinthite from the depth of $90 \mathrm{~cm}$.

Table 2. Morphological attributes of soil profiles of an Experimental Farm "Rafael fernandes" in Mossoró.

\begin{tabular}{|c|c|c|c|c|c|c|c|c|}
\hline \multirow{2}{*}{$\begin{array}{l}\text { Hor./Depth. } \\
\text { (cm) }\end{array}$} & \multirow{2}{*}{$\begin{array}{l}\text { Alt. } \\
(\mathrm{m})\end{array}$} & \multirow{2}{*}{ Color } & \multirow{2}{*}{$\begin{array}{c}\text { Parent } \\
\text { material }\end{array}$} & \multirow{2}{*}{ Structures } & \multicolumn{3}{|c|}{ Consistency } & \multirow{2}{*}{ Trans. } \\
\hline & & & & & Dry & Moist & Wet & \\
\hline \multicolumn{9}{|c|}{ Profile 1 - Typic Rhodustults } \\
\hline$A(0-22)$ & \multirow{5}{*}{78} & 2.5YR 3/6, dry & \multirow{5}{*}{$\begin{array}{c}\text { ARENITO } \\
\text { (Cenozoic, } \\
\text { Barreiras } \\
\text { Group) }\end{array}$} & $1 \mathrm{AB} \mathrm{Gr}$ & So & VFr & NP1 NSt & $\mathrm{Fd}$ \\
\hline $\mathrm{AB}(22-47)$ & & 2.5 YR $4 / 8$, dry & & $1 \mathrm{AB} \mathrm{Gr}$ & So & VFr & NP1 NSt & $\mathrm{Fd}$ \\
\hline BA (47-107) & & 2.5 YR 4/8, dry & & 2A Bls & So & $\mathrm{VFr}$ & LgP1 NPSt & $\mathrm{Fd}$ \\
\hline Bt1 (107-183) & & 2.5 YR $5 / 8$, dry & & 2A Bls & So & VFr & LgP1 St & $\mathrm{Fd}$ \\
\hline \multirow[t]{2}{*}{ Bt2 $(183-233+)$} & & 2.5YR 3/6, dry & & 2AB Bls & So & $\mathrm{Fr}$ & LgP1 St & $\mathrm{Fd}$ \\
\hline & \multicolumn{8}{|c|}{ Profile 2 - Rhodic Haplustox } \\
\hline $\mathrm{A}(0-19)$ & \multirow{5}{*}{90} & 10YR 3/6, dry & \multirow{5}{*}{$\begin{array}{c}\text { ARENITO } \\
\text { (Cenozoic, } \\
\text { Barreiras } \\
\text { Group) }\end{array}$} & $2 \mathrm{AL} \mathrm{Gr}$ & So & VFr & LgP1 St & $\mathrm{Fd}$ \\
\hline $\mathrm{AB}(19-60)$ & & 2.5YR 4/6, dry & & 1LTs Gr & So & $\mathrm{VFr}$ & LgPl NSt & $\mathrm{Fd}$ \\
\hline BA $(60-106)$ & & $2.5 \mathrm{YR} 4 / 8$, dry & & 2AL Bls & So & $\mathrm{VFr}$ & LgPl St & $\mathrm{Fd}$ \\
\hline Bw1 (106-164) & & 2.5 YR $4 / 8$, dry & & 2BA Bla & So & $\mathrm{VFr}$ & Pl St & $\mathrm{Fd}$ \\
\hline \multirow[t]{2}{*}{ Bw2(164-210+) } & & 2.5YR 3/6, dry & & 2BA Bla & So & $\mathrm{Fi}$ & P1 LgSt & $\mathrm{Fd}$ \\
\hline & \multicolumn{8}{|c|}{ Profile 3 - Typic Plinthustalfs } \\
\hline $\mathrm{A}(0-16)$ & \multirow{5}{*}{76} & 10YR 5/4, dry & \multirow{5}{*}{$\begin{array}{c}\text { ARENITO } \\
\text { (Cenozoic, } \\
\text { Barreiras } \\
\text { Group) }\end{array}$} & $1 \mathrm{GBGr}$ & So & VFr & NP1 St & $\mathrm{Fg}$ \\
\hline $\mathrm{AB}(16-34)$ & & 10YR 6/6, dry & & 21BA Bla & So & VFr & LgPl St & $\mathrm{Fg}$ \\
\hline BA (34-92) & & $2.5 \mathrm{YR} 7 / 8$, dry & & 32BA Bls & $\mathrm{H}$ & $\mathrm{Fi}$ & Pl St & $\mathrm{Fc}$ \\
\hline $\operatorname{Btf}(92-141)$ & & $\begin{array}{l}\text { 10R } 4 / 6 \text { (mottled) } \\
2 \text { YR } 8 / 4 \text { (botton) }\end{array}$ & & 3BA Bls & $\mathrm{Eh}$ & VFi & Pl St & $\mathrm{Fg}$ \\
\hline $\operatorname{Crf}(141-194+)$ & & $\begin{array}{c}\text { 10R 3/4 (mottled) } \\
\text { 10YR7/8(botton) }\end{array}$ & & 3L Bls & $\mathrm{Eh}$ & EFi & VP1 St & $\mathrm{Fg}$ \\
\hline
\end{tabular}

Structures: 1 - weark; 2 - moderate; 3 - strong; Ts: too smal; L: little; A: average; B: big; Gr: granular; Bla: angular blocks; Bls: subangular blocks. Consistency: So: softly; Eh: extremely hard; H: hard; Vh: Very hard; VFi: Very firm; Fr: friable; Fi - firm; EFi: Extremely Firm; N: No; V: Very; Lg: lightly; Pl: plastic; St: Sticky. Transition: F: flat; d: diffuse; c: clear; g: gradual.

The granulometric composition of the $\mathrm{P} 1$ showed sandy and loamy sand textures in the surface horizons, and sandy clay loam texture in the subsurface; P2 showed sandy loam texture in the surface horizons, and sandy clay loam and sandy clay in the subsurface; and P3 showed textures varying from sandy to sandy loam in the surface, and sandy clay loam texture in the subsurface (Table 3 ). These compositions contributed to identify the pedogenic processes that occurred in the profiles by understanding the vertical movement of the thinner material that generated more clayey textures in the 
subsurface and sandier textures in the surface, even in the P2, whose predominant process was desilication. The silt-to-clay ratio, used as an indicator of soil weathering stage, was lower than 1 in all profiles, indicating very weathered soils.

Table 3. Physical attributes of soil profiles of an Experimental Farm "Rafael fernandes" in Mossoró.

\begin{tabular}{|c|c|c|c|c|c|c|}
\hline $\begin{array}{l}\text { Hor./Depth. } \\
\text { (cm) }\end{array}$ & $\mathrm{CS}^{(1)}$ & $\begin{array}{r}\mathrm{FS}^{(2)} \\
\mathbf{g}\end{array}$ & Silt & Clay & $\begin{array}{l}\text { Silt/ } \\
\text { Clay }\end{array}$ & Textural class \\
\hline \multicolumn{7}{|c|}{ Profile 1 - Typic Rhodustults } \\
\hline $\mathrm{A}(0-22)$ & 729 & 192 & 20 & 59 & 0.33 & SAND \\
\hline $\mathrm{AB}(22-47)$ & 580 & 262 & 27 & 131 & 0.21 & LOAM SAND \\
\hline BA (47-107) & 502 & 238 & 42 & 219 & 0.20 & SAND CLAY LOAM \\
\hline $\operatorname{Bt1}(107-183)$ & 487 & 239 & 48 & 226 & 0.21 & SAND CLAY LOAM \\
\hline $\mathrm{Bt} 2(183-233+)$ & 419 & 165 & 48 & 369 & 0.13 & SAND CLAY LOAM \\
\hline \multicolumn{7}{|c|}{ Profile 2 - Rhodic Haplustox } \\
\hline $\mathrm{A}(0-19)$ & 486 & 290 & 24 & 200 & 0.12 & SAND LOAM \\
\hline $\mathrm{AB}(19-60)$ & 527 & 258 & 29 & 186 & 0.15 & SAND LOAM \\
\hline BA $(60-106)$ & 535 & 281 & 13 & 166 & 0.08 & SAND LOAM \\
\hline Bw1 (106-164) & 466 & 253 & 37 & 244 & 0.15 & SAND CLAY LOAM \\
\hline Bw2 (164-210+) & 390 & 173 & 39 & 397 & 0.10 & CLAY LOAM \\
\hline \multicolumn{7}{|c|}{ Profile 3 - Typic Plinthustalfs } \\
\hline$A(0-16)$ & 594 & 273 & 43 & 90 & 0.47 & SAND \\
\hline $\mathrm{AB}(16-34)$ & 541 & 228 & 57 & 175 & 0.32 & SAND LOAM \\
\hline BA (34-92) & 407 & 128 & 65 & 400 & 0.16 & SAND LOAM \\
\hline $\operatorname{Btf}(92-141)$ & 412 & 137 & 93 & 358 & 0.26 & SAND CLAY LOAM \\
\hline $\operatorname{Crf}(141-194+)$ & 391 & 127 & 149 & 333 & 0.45 & SAND CLAY LOAM \\
\hline
\end{tabular}

${ }^{1}$ Coarse sand; ${ }^{2}$ Fine sand.

The profiles showed acid reaction in all horizons evaluated (Table 4). The $\mathrm{pH}$ in $\mathrm{KCl}$ were lower than the $\mathrm{pH}$ in $\mathrm{H}_{2} \mathrm{O}$, resulting in a negative $\Delta \mathrm{pH}$ in all profiles, indicating a predominance of negative charges on the colloid surfaces. The total organic carbon (TOC) contents were relatively low in all profiles and horizons (Table 4), due to the semiarid climate, little primary biomass and low and irregular precipitation, which make the plant material decomposition a fast process.

$\mathrm{P} 1$ and P2 showed low base saturation $(\mathrm{V}<50 \%)$ in the subsurface horizons, denoting its dystrophic character, while P3 showed high base saturation ( $\mathrm{V}>50 \%$ ), denoting its eutrophic character (Table 4). Soil from quartz sandstones tend to have little bases, with low nutrient reserves, especially under humid climates, in which the material permeability favors the leaching (KAMPF; CURI, 2009). All soil profiles showed aluminum content below the amount established by the Brazilian System of Soil Classification to characterize them as aluminc or alitic, however, they presented high acidity potential, with low soil $\mathrm{pH}$, especially in the P2. Kampf and Curi (2009) reported that negative charges of clay mineral surfaces are compensated by $\mathrm{H}^{+}$and $\mathrm{Al}^{3+}$, in a base leaching condition caused by weathering.

The $\mathrm{Fe}_{2} \mathrm{O}_{3}$ contents found by sulfuric digestion (Table 4) confirmed the richness of $\mathrm{Fe}$ oxides in the soils, especially in horizons Btf (46.6 g $\left.\mathrm{kg}^{-1}\right)$ and $\mathrm{Crf}\left(62.1 \mathrm{~g} \mathrm{~kg}^{-1}\right)$ of the P3, which showed the highest content of $\mathrm{Fe}_{2} \mathrm{O}_{3}$, due to its wetting and drying cycles that caused $\mathrm{Fe}$ segregation and consequently, $\mathrm{Fe}$ accumulation in subsurface horizons.
The mineralogical composition of the clay fraction of the studied profiles showed that the soils are, basically, kaolinitic-oxidic. In general, the minerals found were similar in all profiles, even in soils that underwent different pedogenic processes. The soil mineralogy is directly connected to the parent material composition, therefore, the fact that all soil profiles described had the same parent material (Table 2) explains this mineral similarity.

The three soil profiles showed well-defined peaks of kaolinite (Kt) (Figure 2), showing a more advanced level of crystallization, which is normal for sediments of soils of the Barreiras Group, due to the intense weathering that the parent material underwent and climatic conditions (MELO et al., 2001). Illite (Il) was found in all profiles, indicating that these soils also have less-weathered minerals, which can be explained by the climatic factor and because illite is a partially expansive, 2:1 mineral.

Goethite (Gt) and hematite (Hm) were found in P1 and P2, with different peaks (Figure 2), explaining the reddish color of these soils. Fe oxides are the main pigment agents in many tropical soils, compared to other mineral groups, regardless of their concentration (MELLO; ALLEONI, 2009). However, less-defined peak formations were found in P3, denoting the more amorphous nature of $\mathrm{Fe}$ oxides, which is due to the influence of the predominant pedogenic process, in which wetting and drying cycles slow the crystallization rate of $\mathrm{Fe}$ oxides, once these alternate cycles indicate new $\mathrm{Fe}$ inputs that adhere to nodes, promoting the crystallization of oxides (KAMPF; CURI, 2009). 
Table 4. Chemical attributes of soil profiles of an Experimental Farm "Rafael fernandes" in Mossoró.

\begin{tabular}{|c|c|c|c|c|c|c|c|c|c|c|c|c|c|c|}
\hline Hor. & $\begin{array}{c}\mathrm{pH} \\
\left(\mathrm{H}_{2} \mathrm{O}\right)\end{array}$ & $\begin{array}{c}\mathrm{pH} \\
(\mathrm{KCl})\end{array}$ & $\Delta \mathrm{pH}$ & $\begin{array}{l}\text { TOC } \\
\mathrm{g} \mathrm{kg}^{-1}\end{array}$ & \multicolumn{6}{|c|}{$\mathrm{cmolc} \mathrm{kg}^{-1}$} & $\begin{array}{c}\mathrm{P} \\
\mathrm{mg} \mathrm{kg}^{-1}\end{array}$ & \multicolumn{2}{|c|}{$(\%)$} & $\begin{array}{l}\mathrm{Fe}_{2} \mathrm{O}_{3} \\
\mathrm{~g} \mathrm{~kg}^{-1}\end{array}$ \\
\hline \multicolumn{15}{|c|}{ Profile 1 - Typic Rhodustults } \\
\hline A & 4.5 & 3.1 & -0.8 & 17.6 & 0.1 & 0.3 & 0.2 & 0.2 & 2.7 & 3.2 & 3.0 & 17 & 23 & 8.1 \\
\hline $\mathrm{AB}$ & 4.6 & 3.6 & -0.1 & 6.8 & 0 & 0.8 & 0.2 & 0.4 & 3.3 & 4.3 & 2.6 & 24 & 26 & 1.2 \\
\hline $\mathrm{BA}$ & 3.6 & 3.7 & -0.9 & 4.0 & 0 & 0.8 & 0.3 & 0.4 & 2.9 & 4.3 & 2.8 & 29 & 26 & 30.5 \\
\hline Bt1 & 3.8 & 3.6 & -0.2 & 2.5 & 0 & 0.6 & 0.3 & 0.4 & 2.6 & 3.1 & 2.3 & 29 & 30 & 28.9 \\
\hline $\mathrm{Bt} 2$ & 3.6 & 3.8 & -0.2 & 1.4 & 0.1 & 0.6 & 0.3 & 0.8 & 2.6 & 3.5 & 2.7 & 27 & 46 & 43.1 \\
\hline \multicolumn{15}{|c|}{ Profile 2 - RHODIC HAPLUSTOX } \\
\hline A & 4.0 & 3.5 & -0.5 & 4.7 & 0.1 & 3.8 & 0.1 & 0.8 & 5.4 & 9.2 & 2.5 & 42 & 17 & 22.9 \\
\hline $\mathrm{AB}$ & 4.6 & 3.7 & -0.8 & 3.3 & 0.1 & 1.8 & 0.2 & 0.7 & 5.2 & 7.2 & 2.5 & 28 & 26 & 22.8 \\
\hline $\mathrm{BA}$ & 4,6 & 3.8 & -0.8 & 2.9 & 0.1 & 0.8 & 0.1 & 0.7 & 5.0 & 5.8 & 1.9 & 15 & 45 & 29.7 \\
\hline Bw1 & 4.3 & 3.7 & -0.6 & 2.9 & 0 & 2.7 & 0.4 & 0.8 & 5.0 & 8.1 & 2.3 & 39 & 20 & 29.2 \\
\hline Bw2 & 4,6 & 3.8 & -0.7 & 2.7 & 0.1 & 1.4 & 0.4 & 1.0 & 5.6 & 7.4 & 2.6 & 26 & 36 & 44.9 \\
\hline \multicolumn{15}{|c|}{ Profile 3 - Typic Plinthustalfs } \\
\hline A & 4.9 & 3.9 & -1.0 & 8.4 & 0.1 & 1.3 & 0.4 & 0.8 & 0.3 & 2.1 & 0.7 & 84 & 31 & 10.3 \\
\hline $\mathrm{AB}$ & 4.5 & 3.8 & -0.7 & 5.8 & 0.2 & 1.0 & 0.4 & 1.0 & 0.4 & 1.9 & 1.4 & 80 & 39 & 16.7 \\
\hline $\mathrm{BA}$ & 4.6 & 3.8 & -0.5 & 5.3 & 0.1 & 1.1 & 0.4 & 1.4 & 0.5 & 2.1 & 0.9 & 78 & 46 & 37.7 \\
\hline Btf & 4.3 & 4.0 & -0.6 & 4.3 & 0 & 0.8 & 0.3 & 0.5 & 0.4 & 1.6 & 1.7 & 77 & 29 & 46.6 \\
\hline $\mathrm{Crf}$ & 5.2 & 4.0 & -0.7 & 4.3 & 0.3 & 1.4 & 0.4 & 0.2 & 0.4 & 2.4 & 1.2 & 86 & 11 & 62.1 \\
\hline
\end{tabular}

${ }^{(1)} \mathrm{TOC}$ - Total organic carbon; ${ }^{(2)} \mathrm{T}-$ Cation exchange capacity; V - Base saturation.

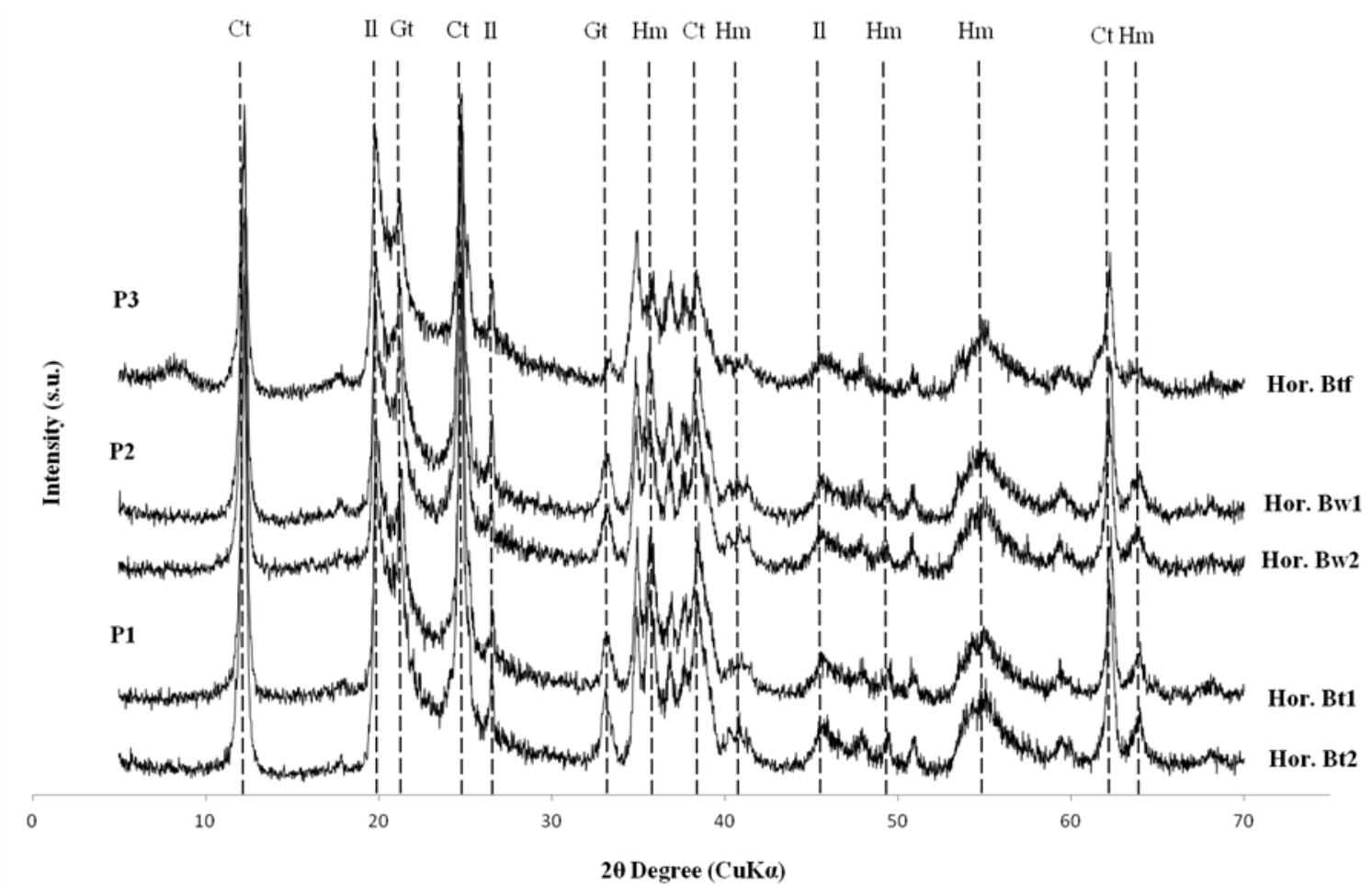

Figure 2. X-ray diffractometry (XRD) the clay fraction profiles of diagnostics horizons in: Typic Rhodustults (P1); Rhodic Haplustox (P2) e Typic Plinthustalfs (P3). Ct: kaolinite; Il: Illite; Gt: Goethite; Hm: Hematite. 


\section{CONCLUSIONS}

The morphological, physical, chemical and mineralogical characteristics of the soil profiles evaluated showed the influence of the formation factors paternal material and relief in the pedogenic processes, which generated more developed soils, even under their semiarid climatic conditions. The three soil types found in the studied experimental farm were Typic Rhodustults (P1), Rhodic Haplustox (P2) and Typic Plinthustalfs (P3). The profiles showed, in general, a structure that remains granular in the surface horizons and changes to sub-angular blocks in the subsurface horizons. The textures found in the soil profiles showed surface horizons with sandier texture and subsurface horizons with more clayey texture. The chemical attributes showed total organic carbon (TOC) contents relatively low, dystrophic character in P1 and P2 and eutrophic character in P3. The clay fraction of the soil profiles showed mineralogical composition with predominance of kaolinite, illite and presence of the Fe oxides goethite and hematite.

\section{REFERENCES}

CARMO FILHO, F.; OLIVEIRA, O. F. Mossoró: um município do semi-árido nordestino, caracterização climática e aspecto florístico. Mossoró: ESAM, 1995. 62 p. (Coleção Mossoroense, Série B).

CHEN, P.Y. Table of key lines in X-ray powder diffraction patterns of minerals in clays and associated rocks: Geological Survey Occasional Paper 21. Bloomington: Indiana Geological Survey Report. 1977. v. 3, p. 67.

DONAGEMA, G. K. et al. Manual de métodos de análise de solos. Rio de Janeiro: Embrapa Solos, 2011. v. 2, p. 230, (Embrapa Solos. Documentos, 132).

KAMPF, N.; CURI, N. Formação e Evolução do Solo: Pedogênese. In: KER, J.C.; CURI, N.; SCHAEFER, C.E.R. \& TORRADO, P.V., eds. Pedologia: Fundamentos. Viçosa, MG: Sociedade Brasileira de Ciência do Solo, 2009. v. 1 cap. 7, p. 207-302.

MELO, V.F.; SINGH, B.; SCHAEFER, C.E.G.R.; NOVAIS, R.F.; FONTES, M.P.F. Chemical and mineralogical properties of kaolinite-rich Brazilian soils. Soil Science Society of America Journal, Madison, v. 65, n. 4, p. 1324-1334, 2001.

MELlO, V. F.; ALleONI, L. R. F., Química e Mineralogia do Solo, parte 1: Óxidos de ferro. ed. 1
Viçosa, MG: Sociedade Brasileira de Ciência do Solo, 2009. p. 695.

PROJETO RADAMBRASIL. Levantamento de Recursos Naturais. ed. 23, Folhas SB.24/25 Jaguaribe/ Natal. Rio de Janeiro: Ministério das Minas e Energia, 1981. p. 739.

RESENDE, M.; Curi, N., Rezende, S.B. \& CORRÊA, G.F. Pedologia: base para distinção de ambientes. Lavras, MG: Editora UFLA, 2014. v. 6, Cap. 5, p. 109-147.

SANTOS, H. G. et al. Sistema brasileiro de classificação de solos. 3. ed. Brasília: Embrapa, 2013b. p. 353.

SANTOS, R. D. et al. Manual de descrição e coleta de solo no campo. 6. ed. Viçosa: Sociedade Brasileira de Ciência do Solo, 2013a. p. 100.

SERVIÇO GEOLÓGICO DO BRASIL - CPRM. Geodiversidade do estado do Rio Grande do Norte. Recife, 2010. p. 227.

SERVIÇO NACIONAL DE LEVANTAMENTO E CONSERVAÇÃO DE SOLOS-EMBRAPA. Levantamento Exploratório - Reconhecimento de solos Rio Grande do Norte (Área de atuação da SUDENE), Boletim Técnico $\mathrm{n}^{\circ}$ 60. Recife, 1971. $531 \mathrm{p}$.

VETTORI, L. Métodos de análise de solo.(Boletim Tecnico.7).Rio de Janeiro: Equipe de Pedologia e Fertilidade do Solo, 1969. p. 34.

YEOMANS, J. C., BREMNER, J. M. A rapid and precise method for routine determination of carbon in soil. Communications in Soil Science and Plant Analysis, Nova Iorque, v. 19, n. 13, p. 1467-1476, 1988. 